\title{
Reproductive and Child Healthcare based Subnational Gender Development Index: A New Approach
}

\author{
Ananya Mishra*, Anurag Banerjee and Arvind Narayan Mishra \\ Research Analyst, Social Consultancy Services \\ *Correspnding author: ananya123mishra@gmail.com (ORCID ID: 0000-0003-3425-4933)
}

Received: $13-11-2020$

Revised: 20-02-2021

Accepted: 05-03-2021

\begin{abstract}
Traditional metrics of gender development have failed to capture social dynamics that hinder gender equality, the inadequacies in reproductive health. As a policy instrument, traditional indices are inadequate for state governments to tackle regional issues in gender justice. This paper develops an index which can be used by states to determine particular areas of intervention and to track their progress.

Methodology: The study develops an index based on six pillars. Under each pillar, the states are scored on a set of variables based on the quartiles of their scores. This scoring is scaled and the geometric mean of the score on each pillar is used as final index. The study then clusters the states based on their index scores and uses dimensionality reduction using Principal Component Analysis to arrive at dimensions for intervention.

Result: Index scores indicates that the states perform well on some while fail on other dimensions challenging traditional notions and stereotypes of states being labelled as "sexist" or "feminist". The study highlights: "Position of Women in Society", "Access to Reproductive and Child Health" and "Economic Empowerment" as key dimensions of intervention for states and based on their scores, recommends policy action for each dimension.
\end{abstract}

\section{Highlights}

(0 The study develops an index based on six broad pillars: Social, Capacity, Reproductive Care and Health, Health, Nutrition and Economic.

(0 Position of women in Society, access to reproductive and child healthcare service and economic rights are the major parameters which determine the gender index.

(- As per GDI (Gender Development Index) scores, South and North-Eastern states have been the achievers whereas the Eastern and Central states which constitutes the BIMARU group have been aspirants in the GDI scores.

Keywords: Gender Development Index, Reproductive and Child healthcare, Principal component analysis, Clustering

Issues of Gender Development in India range from the traditional issues like meta-preference for sons (Economic Survey, Government of India, 2018), Declining sex ratios, declining female labour force participation rates, domestic violence to modern issues such as representation of women in media, sexual harassment at workplace, assault on women among others. The issues that have remained relevant in last decade in India have focused on crimes against women, security, amendment of customs and practises that are

How to cite this article: Mishra, A., Banerjee, A. and Mishra, A.N. (2021). Reproductive and Child Healthcare based Subnational Gender Development Index: A New Approach. Int. J. Soc. Sci., 10(01): 01-14.

Source of Support: None; Conflict of Interest: None (9) 9 
regressive such as Triple talaq, ban on temple entry of women, representation in armed forces. As pertinent as these issues are, there still exists a gap in basic public service delivery in terms of quality education, health, nutrition among other aspects.

The scale of conventional metrics and indices quantifying gender equality in India are based on Health, Education and Quality of Life. They take into account the life expectancy, the mean year of schooling and the income levels. Gender Inequality Index attempts to broad base the index using more precise metrics focusing on Health: Maternal Mortality Rate, Adolescent Birth Rate as measure of female reproductive health index, Empowerment: percentage of women with secondary education and share of seats in Parliament, and lastly labour force participation rate as measure of employability and economic opportunities. The index is meant to highlight areas of policy making that can be focused to reduce inequalities in development indicators between men and women.

"The GII sheds new light on the position of women in 162 countries; it yields insights in gender gaps in major areas of human development. The component indicators highlight areas in need of critical policy intervention and it stimulates proactive thinking and public policy to overcome systematic disadvantages of women" (HDR, 2020).

However, such indices cover nations, and in doing so miss out the variations across the States. It leads to policy makers focusing on a top down approach, wherein the interventions for gender development are institutional such as Gender based Budgeting or creating separate funds catering to a Gender issue or amending a criminal law. However, at the core of gender inequality lies social stereotypes, social positioning of a woman and family dynamics that affect women by hindering their access to institutional arrangements. An illustration of this trend is the "Panchayat Pati" phenomenon in rural India, where the one-third reservation for women in Sarpanch elections are countered by the family dynamics wherein bulk of decisions are actually taken by the spouse of such female Sarpanch, defeating the point of all these measures. Similarly, enacting Pre-conception Pre-Natal
Diagnostic Test Act (PCPNDTA) may have prevented sex selective abortions but the Meta-preference for sons has in turn led to unwanted girl child across country, as documented in the Economic Survey 2018.

Currently, Gender Issues and Policy challenges are framed at National level. The policies are based on indices which are not easy to track and set targets at State or district level. Secondly, many such indices take into account institutional and macroscopic indicators like Life Expectancy and Mean year of schooling. Similarly, such indicators are institutional and something that can be corrected by mere provisioning. However, subjugation of women, manifestation of patriarchy and status of women in family, society are more nuanced, deep rooted. Therefore, the society has deep seated gender issues which need to be addressed, broad basing the intent of existing Gender Development Indicators

In this regard, the study attempts to develop Gender Development Index based on aspects that are fundamental for development. Such issues cover not only tangible aspects such as nutrition and well being but also socio-economic factors that can describe the status of women in the society. The index is a point of convergence of multiple Sustainable Development Goals: SDG-3 for "Good Health and Well Being", SDG-5 for "Gender Equality", SDG-2 for "Zero Hunger" and SDG-4 "Quality Education ". Therefore, the index is an opportunity to track the performance of individual States with respect to multiple SDGs. More importantly, it gives the States the opportunity to develop tangible targets for Gender Equality moving from Gender Budgeting to a more elaborate institutional attempt to tackle issues hampering Gender Equality in India.

This index therefore attempts to include indicators that are broader based, that capture social dynamics, are more granular. They assume that core areas of governance such as Health, Education are implemented on ground by the States and therefore a measure of the states will not only track performance, delineate the weak spots for every state but can also foster competitiveness among States by becoming a criterion for horizontal devolution through finance commissions. 


\section{Literature Review}

Gender Development Indices have been developed by multilateral organizations like United Nations to track levels of gender development since 1995. Such gender development indices are based on Education, health and quality of life. However, such gender indices were created to attract attention towards gender equality and not for policy planning in itself. This has led to misinterpretation of GDI (Schuler, 2006). Therefore, the measure was meant to add a gender-based approach to development, and not centred on gender in itself.

In case of India the initial gender-based index were mostly in the form of human development reports of the states. The most common mistakes found in these was that the GDI was used to interpret it as a measure of gender inequality. Many such studies present both correct and incorrect interpretations. This establishes the fact that computation of the GDI is not understood very well. In case of India works like Bhatia (2002), Dholakia (2005), Mehta (1996) have tried to formulate gender index based on political representation, labour participation, fertility etc. The HDR's of several Indian states too focuses on labour participation, political representation etc. The issues with such representation are firstly, that they do not adequately reflect gender inequality dimensions neither in developing countries, nor in developed nations. Secondly, there are significant shortcomings in the analysis of gender issues in national and subnational reports which is reflected by the lack of adequate data and deeper descriptive analysis thereby reducing the possibilities for their influence on policy (Schuler, 2006). Therefore, in this paper we try to use these principles and try to focus gender index through a lens of a particular theme by following an in-depth analysis of NFHS 4 based data to look into the health, social and economic access of women across India. Till now there has not been much studies in developing and gender centric index based on NFHS 4 data. Few studies like Singh et al. (2019), Rai et al. (2018) have looked into the aspect of women in India examining the issues in context of anaemia and HIV. But there hasn't been extensive work done to use the data to formulate an index. This leaves a wide scope to explore the data set to formulate a gender index.
If existing indices are meant to track development, they are inadequate. Firstly, the indices do not offer State wise perspective. Therefore, as a tool for policy making it lacks the granularity to allow decentralized policy making. This moves the focus away from States and puts the burden of gender empowerment policies on the Central government. This in turn can lead to one size fits all, which can be counterproductive as the causes of gender inequality in different states are different as shown in the index levels. Secondly, there is no mechanism to track all such metrics for independent States or districts, mostly because of data deficiency. This hinders the State from tracking gender development levels in the State, and creating a lacuna as far as gender development policies are concerned. Thirdly, most of these indicators are institutional or macroscopic, not touching upon issues that affect "common women".

Such indices describe the general sense of gender inequality in the country as a whole and not as a measure that can be used to compare and cluster the state. With policy making decentralizing, and State based indices being developed by NITI Aayog such as indices on Health, Water and overall SDG indices, a gender index in the country can help in mapping out, comparing and tracking each state. Moreover, with development in the country becoming more centred around Sustainable Development Goals, it is imperative that issues of women that are represented in the SDGs are also targeted by policymakers. The index therefore, also offers the opportunity to link pillars of index with Sustainable Development Goals. The index developed in the past decades have not been able to actualize any of the earmarked issues. Moreover, instances of low utilization such as gender-based budget indicate towards a lower priority accorded to the societal issues that perpetuate gender-based injustices. So, while we have laws, funds and provisions, unless we do not have focus on indicators that measure current state of affairs of women as part of society and levels of their agency, we cannot determine how empowered they are. In this paper we try to define the scope of index reflecting a particular theme with the to give a clear picture of the "state of affairs" of women and compare the States to find the best and the worst. 


\section{Methodology}

The methodology of this study is divided into three steps. The study focuses on developing an index and assess the state wise performance based on the index, cluster them on basis of the performance and use dimensionality reduction to arrive at fundamental dimensions for policy targeting.

\section{Selection of pillars}

The study aims to develop an index based on six broad pillars: health, reproductive and child health, social, capacity, nutrition and economic factors. The six pillars have a total of 24 variables in total. The description of each variable and its pillar are given at the end of the paper. The study uses secondary data from the Ministry of Health and Family Welfare, National Family Health Survey 4 (2015-16), co-ordinated by International Institute for Population Sciences, Mumbai.

\section{Grouping of states:}

According to literature the states have often been grouped together on the geographic location, socioeconomic performance as well as cultural connection. Hence to bring out a nuanced regional aspect the states in this case the states have been grouped in the following manner:

(a) Hilly States (North India): This region includes Jammu and Kashmir, Uttarakhand, Himachal Pradesh. The region is identified by very socioeconomic features.

(b) North-eastern States: This region includes Sikkim, Arunachal Pradesh, Assam, Manipur, Meghalaya, Mizoram, Nagaland, Tripura.

(c) North Indian: This region includes Punjab, Haryana, Uttar Pradesh, Bihar, Madhya Pradesh. This region is characterized by poor performance in socio-economic parameters. Uttar Pradesh, Bihar, Madhya Pradesh, infamously was a part of "BIMARU” states.

(d) West India: This region includes the states of Rajasthan, Gujarat, Maharashtra, and Goa.

(e) South India: This region includes the state of
Andhra Pradesh, Karnataka, Kerala, Tamil Nadu, and Telangana.

(f) East India: This region includes the states of Jharkhand, Chhattisgarh, Odisha, and West Bengal.

\section{Index calculation}

The index determines the scores for each aspect. In calculation of score in each aspect a State is scored on a scale of one to four based on the quartile in which it is placed. As the score of the state moves from first to fourth quartile the score moves from 1 to 4 . The States are scored for all variables in the pillar and then the scores are aggregated and divided by the total score possible within a pillar. This gives a score on the scale of 1 for every state on every pillar. These scores are used to determine aspirant and performing States in each aspect. This score is the basis for identification of areas of intervention in each aspect. The final GDI is determined as the geometric mean of the scores in each pillar.

Geometric mean is used because poor performance in any dimension is directly reflected in the geometric mean. In other words, a low achievement in one dimension is not linearly compensated for by a higher achievement in another dimension. The geometric mean reduces the level of substitutability between dimensions and at the same time ensures that a unit decline in the index is same as one percent decline in the any other parameter of the index. Thus, as a basis for comparisons of achievements, this method is also more respectful of the intrinsic differences across the dimensions than a simple average. The GDI was computed in $\mathrm{R}$ and the all the parameters were given equal weights in the geometric mean index.

\section{Principal Component Analysis and K-Means Clustering}

To achieve dimensionality reduction, the study uses Principal Component Analysis to identify principal components which can describe the variations in the original index scores and act as broad indicators that encapsulate more than one original indicators. It is used to determine the fundamental dimensions for policy intervention. 
Based on their performance on the index, the states are clustered using K-Means clustering. The basic idea behind $\mathrm{k}$-means clustering consists of defining clusters so that the total intra-cluster variation (known as total within-cluster variation) is minimized.

These clusters are then identified as "Achievers", "Performers" and "Aspirants "based on the index.

For each state the following steps were undertaken:

* Identifying those pillars in which the state performs below a benchmark ( 0.5 for Aspirant and 0.625 for Performers) OR

* the score of the state in that pillar is lower than the final index score of the state.

Based on these criteria, we identify the original pillar that the state needs to improve in and based on them, the fundamental dimensions in which the intervention is required. The heatmaps, the PCA Analysis, Clustering and Index preparation was conducted on R. Data Compilation and Charting was prepared on Excel.

\section{Analysis}

The state wise performances for each of the six pillars have been computed to highlight the issues. The pillar wise assessment is as follows:

\section{Social}

Social parameter tries to gauge the societal position through indicators like literacy, sex ratio and violence faced. The social index performance is given in the figure

Table 1: State wise grouping based on social index performance in terms of quartile

\begin{tabular}{|l|l|l|}
\hline Quartiles & States & Description \\
\hline $1^{\text {st }}$ & $\begin{array}{l}\text { Andhra Pradesh, Bihar, } \\
\text { Jharkhand, Madhya } \\
\text { Pradesh, Rajasthan, } \\
\text { Telangana, Uttar Pradesh, } \\
\text { Arunachal Pradesh }\end{array}$ & $\begin{array}{l}\text { These states have } \\
\text { a below average in } \\
\text { majority of the 5 } \\
\text { indicators. }\end{array}$ \\
\hline $\begin{array}{l}2^{\text {nd }} \\
\text { Quartile }\end{array}$ & $\begin{array}{l}\text { Assam, Gujarat, Haryana, } \\
\text { Karnataka, West Bengal, } \\
\text { Chhattisgarh, Maharashtra, } \\
\text { Odisha }\end{array}$ & $\begin{array}{l}\text { These states have } \\
\text { average performance } \\
\text { in the majority of the } \\
\text { indicators with a below } \\
\text { average performance in } \\
\text { the remaining ones. }\end{array}$ \\
\hline
\end{tabular}

\begin{tabular}{|l|l|l|}
\hline $\begin{array}{l}3^{\text {rd }} \\
\text { Quartile }\end{array}$ & $\begin{array}{l}\text { Tamil Nadu, Tripura, } \\
\text { Punjab, Jammu \& Kashmir, } \\
\text { Meghalaya, Nagaland, } \\
\text { Sikkim and Uttarakhand }\end{array}$ & $\begin{array}{l}\text { These states have } \\
\text { majority of scores } \\
\text { between 2 and 3, outlier } \\
\text { scores are compensated. }\end{array}$ \\
\hline $4^{\text {th }}$ & $\begin{array}{l}\text { Kerala, Mizoram, } \\
\text { Quartile } \\
\text { Himachal Pradesh, Goa, } \\
\text { Manipur }\end{array}$ & $\begin{array}{l}\text { These States have a very } \\
\text { high score, between 3-4 } \\
\text { in majority of indicators. }\end{array}$ \\
\hline
\end{tabular}

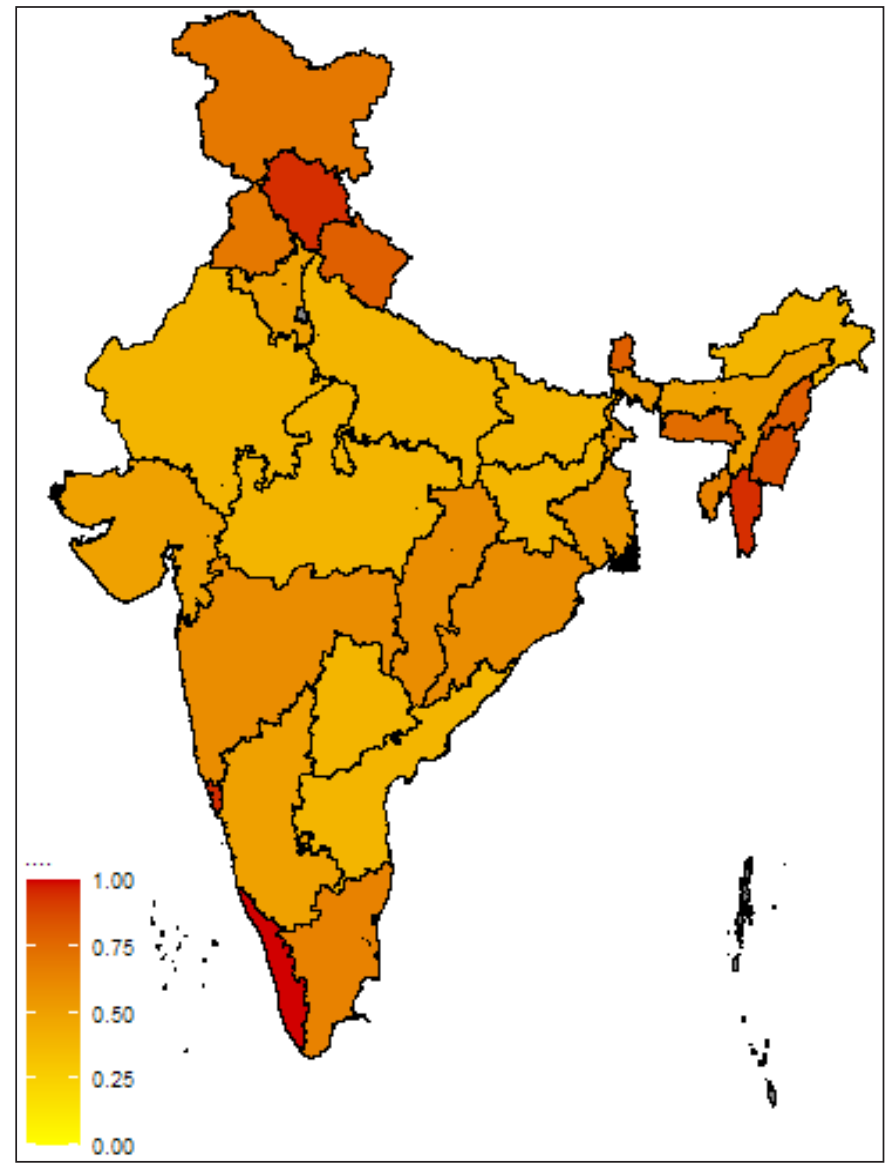

Fig. 1: Heat map of the state wise performance in social pillar

\section{Geographical Interpretation}

* There is not a very strong linkage of the region and the scoring pattern. The West Indian belt include varying degree of performances. Similarly, the southern states have a spectrum of scores across the states.

* There are areas with a fairly homogenous scoring pattern. The Eastern belt has a very homogenous score on the index. The Hindi heartland has some of the lowest scores from Rajasthan, Uttar Pradesh, 
Madhya Pradesh, Bihar, Jharkhand having the lowest scores. The northern hilly states too have a homogenous scoring, performing better than the states of the plain.

* The North Eastern states have a majority of high scores in the region and the hilly states in general, including the ones in the north have a score higher than the scores in the plains. Barring one or two states, it forms one of the best performing clusters in the country.

\section{Capacity}

Capacity as an indicator is a measure of awareness and ability of a woman in a household.

Table 2: State wise grouping based on capacity index performance in terms of quartile

\begin{tabular}{|l|l|l|}
\hline Quartiles & States & Description \\
\hline $\begin{array}{l}1^{\text {st }} \\
\text { Quartile }\end{array}$ & $\begin{array}{l}\text { Andhra Pradesh, Bihar, } \\
\text { Jharkhand, Madhya } \\
\text { Pradesh, Rajasthan, } \\
\text { Telangana, Uttar Pradesh, } \\
\text { Arunachal Pradesh }\end{array}$ & $\begin{array}{l}\text { These states have } \\
\text { a below average in } \\
\text { majority of the 3 } \\
\text { indicators. }\end{array}$ \\
\hline $\begin{array}{l}2^{\text {nd }} \\
\text { Quartile }\end{array}$ & $\begin{array}{l}\text { Assam, Gujarat, Haryana, } \\
\text { Karnataka, West Bengal, } \\
\text { Chhattisgarh, Maharashtra, } \\
\text { Odisha }\end{array}$ & $\begin{array}{l}\text { These states have } \\
\text { average performance } \\
\text { in the majority of the } \\
\text { indicators with a below } \\
\text { average performance in } \\
\text { the remaining ones. }\end{array}$ \\
\hline $\begin{array}{l}3^{\text {rd }} \\
\text { Quartile }\end{array}$ & $\begin{array}{l}\text { West Bengal, Odisha, } \\
\text { Meghalaya, Manipur, } \\
\text { Haryana, Uttarakhand, } \\
\text { Kerala }\end{array}$ & $\begin{array}{l}\text { These states have } \\
\text { majority of scores } \\
\text { between 2 and 3, } \\
\text { outlier scores are } \\
\text { compensated. }\end{array}$ \\
\hline $4^{\text {th }}$ \\
Quartile & $\begin{array}{l}\text { Tamil Nadu, Punjab, } \\
\text { Sikkim, Himachal Pradesh, } \\
\text { Goa, Mizoram }\end{array}$ & $\begin{array}{l}\text { These States have } \\
\text { a very high score, } \\
\text { between 3-4 in majority } \\
\text { of indicators. }\end{array}$ \\
\hline
\end{tabular}

\section{Geographical Interpretation}

* There is not a very strong linkage of the region and the scoring pattern. The West Indian belt includes varying degree of performances. Similarly, the southern states have a spectrum of scores across the states.

* There are areas with a fairly homogenous scoring pattern. The Eastern belt has a very homogenous score on the index. The Hindi heartland has some of the lowest scores from Rajasthan, Uttar Pradesh, Madhya Pradesh, Bihar, and Jharkhand having the lowest scores. The northern hilly states to have a homogenous scoring, performing better than the states of the plain.

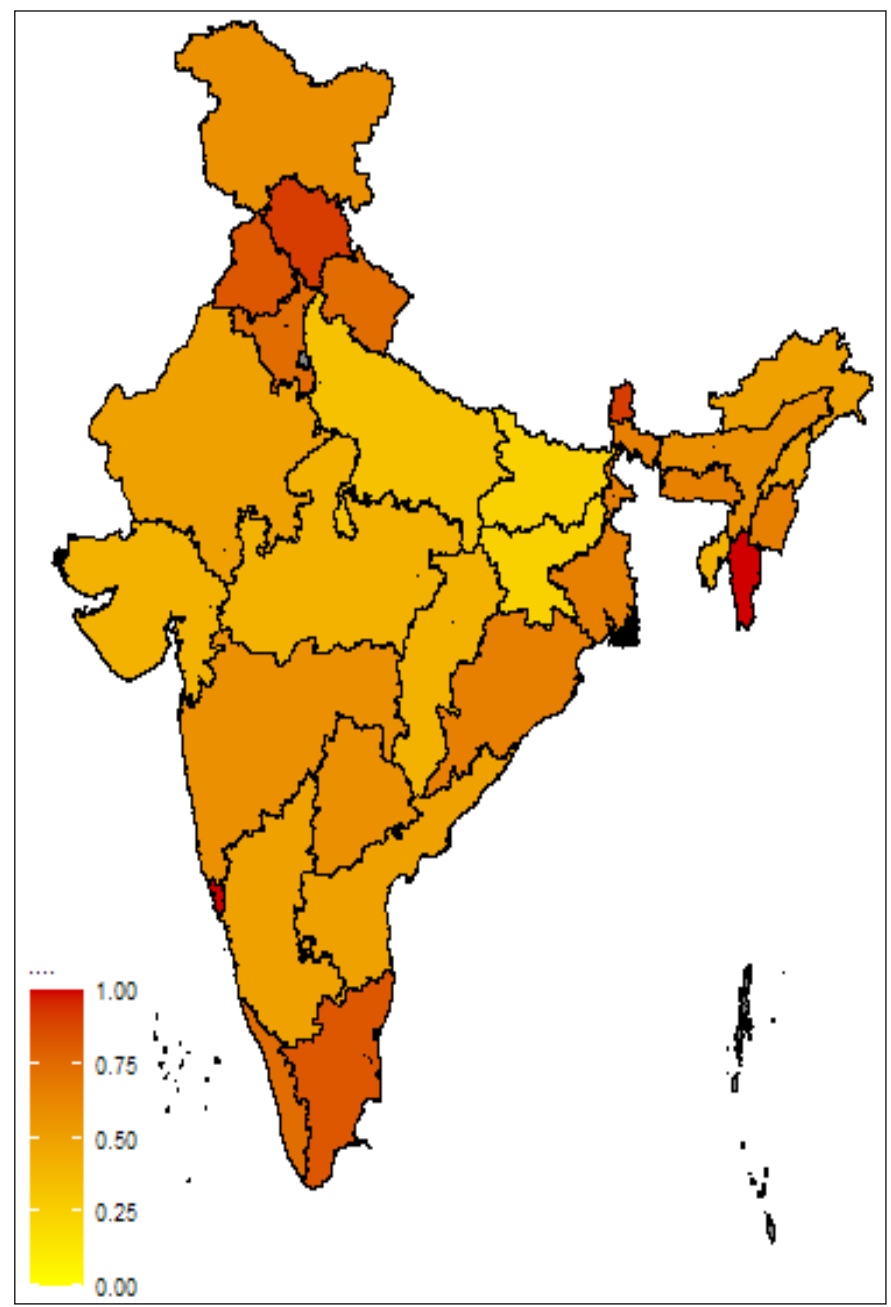

Fig. 2: Heat map of the state wise performance in capacity dimension

* The North-eastern states have a majority of high scores in the region and the hilly states in general, including the ones in the north have a score higher than the scores in the plains. Barring one or two states, it forms one of the best performing clusters in the country. 


\section{Health}

This pillar measures indicators that track lifestyle disorders and general hygiene.

Table 3: State wise grouping based on health index performance in terms of quartile

\begin{tabular}{|l|l|l|}
\hline Quartiles & States & Description \\
\hline $\begin{array}{l}1^{\text {st }} \\
\text { Quartile }\end{array}$ & $\begin{array}{l}\text { Assam, Bihar, Jharkhand, } \\
\text { Odisha, Uttar Pradesh, West } \\
\text { Bengal, Nagaland, Tripura }\end{array}$ & $\begin{array}{l}\text { These states have } \\
\text { a below average in } \\
\text { majority of the 5 } \\
\text { indicators. }\end{array}$ \\
\hline $\begin{array}{l}2^{\text {nd }} \\
\text { Quartile }\end{array}$ & $\begin{array}{l}\text { Andhra Pradesh, } \\
\text { Chhattisgarh, Karnataka, } \\
\text { Rajasthan, Arunachal } \\
\text { Pradesh, Manipur, } \\
\text { Mizoram, Sikkim, } \\
\text { Uttarakhand }\end{array}$ & $\begin{array}{l}\text { These states have } \\
\text { average performance } \\
\text { in the majority of the } \\
\text { indicators with a below } \\
\text { average performance in } \\
\text { the remaining ones. }\end{array}$ \\
\hline $3^{\text {rd }}$ \\
Quartile & $\begin{array}{l}\text { Gujarat, Kerala, Madhya } \\
\text { Pradesh, Tamil Nadu, } \\
\text { Telangana, Goa, Himachal } \\
\text { Pradesh, Meghalaya }\end{array}$ & $\begin{array}{l}\text { These states have } \\
\text { majority of scores } \\
\text { between 2 and 3, } \\
\text { outlier scores are } \\
\text { compensated. }\end{array}$ \\
\hline $\begin{array}{l}4^{\text {th }} \\
\text { Quartile }\end{array}$ & $\begin{array}{l}\text { Haryana, Maharashtra, } \\
\text { Punjab, Jammu \& Kashmir }\end{array}$ & $\begin{array}{l}\text { These States have } \\
\text { a very high score, } \\
\text { between 3-4 in majority } \\
\text { of indicators. }\end{array}$ \\
\hline
\end{tabular}

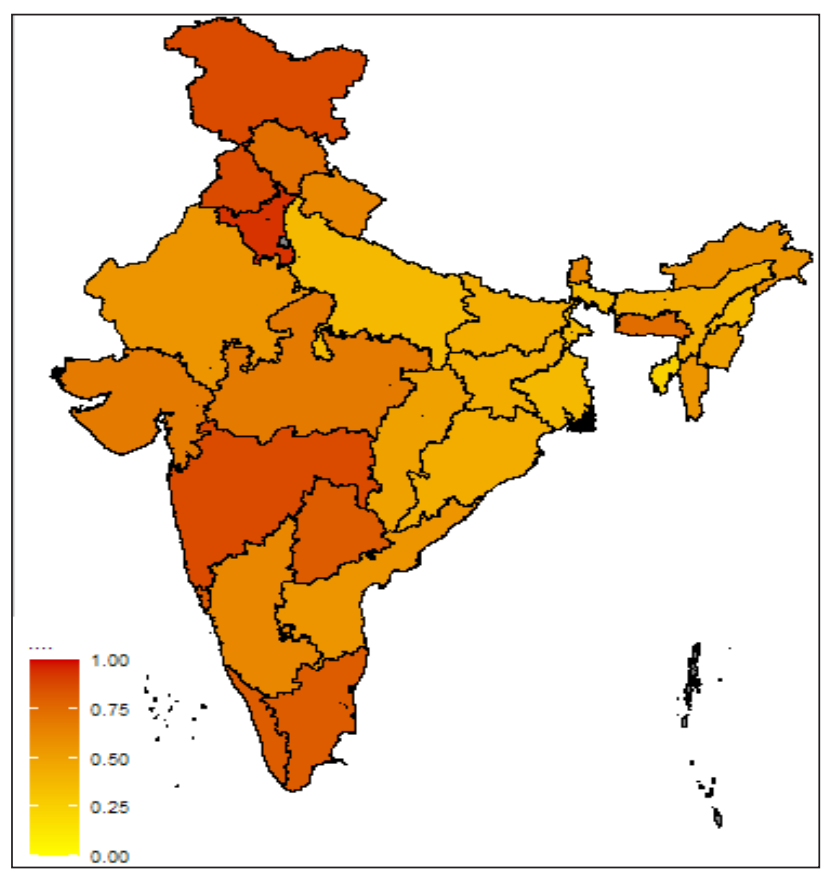

Fig. 3: Heat map of the state wise performance in health dimension

\section{Geographical Interpretations}

* Geographically, rural urban divide in majority areas in health is not well defined, with close score on the indicator by States.

* In general, the northern Hills, Western India and Southern states have performed well on the indicator.

* On the other hand, states in North East have scored below average, barring Meghalaya, with traditional high scores Mizoram and Sikkim struggling to score high on the index as well. Similarly, Eastern states have scored below average on the index.

* The Northern states are a mixed bag, with Haryana and Punjab performing above national average and UP, MP and Bihar struggling with low scores.

\section{Economics}

Economic parameters Is taken into account to understand the access to economic resources to women. This includes land and also safety nets such as financial services, assets etc.

Table 4: State wise grouping based on economic dimension performance in terms of quartile

\begin{tabular}{|l|l|l|}
\hline Quartiles & States & Description \\
\hline $1^{\text {st }}$ & $\begin{array}{l}\text { Qhhattisgarh, Gujarat, } \\
\text { Haryana, Jharkhand, } \\
\text { Madhya Pradesh, } \\
\text { Maharashtra, Mizoram, } \\
\text { Nagaland, Rajasthan, } \\
\text { Uttarakhand, West Bengal }\end{array}$ & $\begin{array}{l}\text { These states have } \\
\text { a below average } \\
\text { in majority of the } \\
\text { indicators . }\end{array}$ \\
\hline $2^{\text {nd }}$ & $\begin{array}{l}\text { Assam, Bihar, Himachal } \\
\text { Quartile } \\
\text { Kashmir, Karnataka, } \\
\text { Manipur, Punjab, Sikkim, } \\
\text { Uttar Pradesh }\end{array}$ & $\begin{array}{l}\text { These states have } \\
\text { average performance } \\
\text { in the majority of the } \\
\text { indicators with a below } \\
\text { average performance in } \\
\text { the remaining ones. }\end{array}$ \\
\hline $3^{\text {rd }}$ \\
Quartile & $\begin{array}{l}\text { Arunachal Pradesh, Goa, } \\
\text { Meghalaya, Tamil Nadu }\end{array}$ & $\begin{array}{l}\text { These states have } \\
\text { majority of scores } \\
\text { between 2 and 3, } \\
\text { outlier scores are } \\
\text { compensated. }\end{array}$ \\
\hline $4^{\text {th }}$ \\
Quartile & $\begin{array}{l}\text { Andhra Pradesh, Kerala, } \\
\text { Orissa, Telangana, Tripura }\end{array}$ & $\begin{array}{l}\text { These States have } \\
\text { a very high score, } \\
\text { between 3-4 in majority } \\
\text { of indicators. }\end{array}$ \\
\hline
\end{tabular}




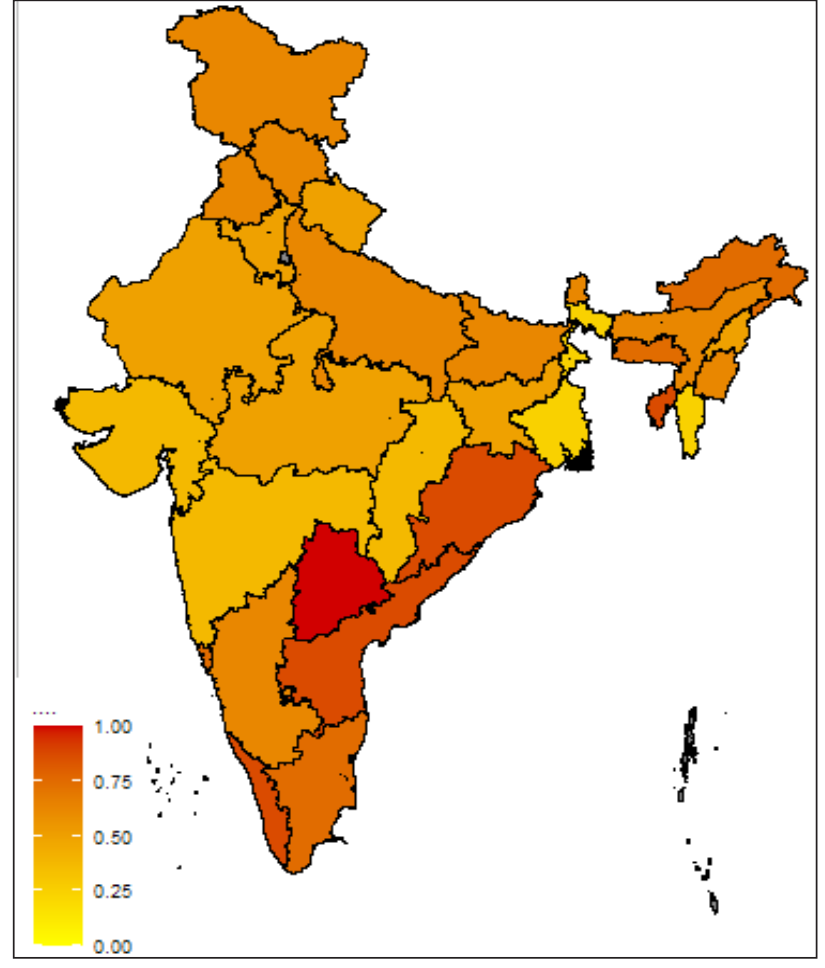

Fig. 4: Heat map of the state wise performance in Economic dimension

\section{Geographical Interpretations}

* The top performers of the index are the Southern states, with low Rural-Urban divide hinting to the success of self-help group schemes like Kudumbashree in Kerala and Velugu in erstwhile united Andhra Pradesh. The region sees these three states (Kerala, Andhra Pradesh and Telangana) registering higher scores in rural areas probably due to such SHG movements.

* In North India, Punjab performs well on percentage of women with bank accounts, while UP and Bihar perform well in land ownership percentage, a phenomenon attributed to "Feminization of Agriculture" in Economic Survey 2017, in which migration from such states and welfare scheme conditions have led to increased female land ownership.

* In Hilly and North Eastern States, the performance is mostly low to average scoring barring exceptions
Arunachal Pradesh and Tripura. In north hill states, land ownership among women is muted, while in low scoring North-East states, the percentage of women with access to bank accounts is low.

\section{Reproductive and Child Health}

This indicator records the access to quality healthcare to women with respect to childbirth.

Table 5: State wise grouping based on $\mathrm{RCH}$ index performance in terms of quartile

\begin{tabular}{|c|c|c|}
\hline Quartiles & States & Description \\
\hline $\begin{array}{l}1^{\text {st }} \\
\text { Quartile }\end{array}$ & $\begin{array}{l}\text { Arunachal Pradesh, Assam, } \\
\text { Bihar, Jharkhand, Manipur, } \\
\text { Meghalaya, Mizoram, } \\
\text { Nagaland, Uttar Pradesh, } \\
\text { Uttaranchal }\end{array}$ & $\begin{array}{l}\text { These states have } \\
\text { a below average in } \\
\text { majority of the } 5 \\
\text { indicators. }\end{array}$ \\
\hline $\begin{array}{l}2^{\text {nd }} \\
\text { Quartile }\end{array}$ & $\begin{array}{l}\text { Chhattisgarh, Himachal } \\
\text { Pradesh, Madhya Pradesh, } \\
\text { Orissa, Rajasthan, Tripura }\end{array}$ & $\begin{array}{l}\text { These states have } \\
\text { average performance } \\
\text { in the majority of the } \\
\text { indicators with a below } \\
\text { average performance in } \\
\text { the remaining ones. }\end{array}$ \\
\hline $\begin{array}{l}3^{\text {rd }} \\
\text { Quartile }\end{array}$ & $\begin{array}{l}\text { Goa, Gujarat, Haryana, } \\
\text { Jammu and Kashmir, } \\
\text { Karnataka, Kerala, } \\
\text { Maharashtra, Sikkim, West } \\
\text { Bengal }\end{array}$ & $\begin{array}{l}\text { These states have } \\
\text { majority of scores } \\
\text { between } 2 \text { and } 3, \\
\text { outlier scores are } \\
\text { compensated. }\end{array}$ \\
\hline $\begin{array}{l}4^{\text {th }} \\
\text { Quartile }\end{array}$ & $\begin{array}{l}\text { Andhra Pradesh, Punjab, } \\
\text { Tamil Nadu, Telangana }\end{array}$ & $\begin{array}{l}\text { These States have } \\
\text { a very high score, } \\
\text { between } 3-4 \text { in majority } \\
\text { of indicators. }\end{array}$ \\
\hline
\end{tabular}

\section{Geographical Interpretations}

* Overall, the performance in Northeast remains poor, barring Sikkim and Tripura.

* In North India, UP and Bihar score low while Punjab and Haryana form the upper end of the region

* In Southern states, all the states are in the fourth quartile, indicating excellent infrastructure and access. 


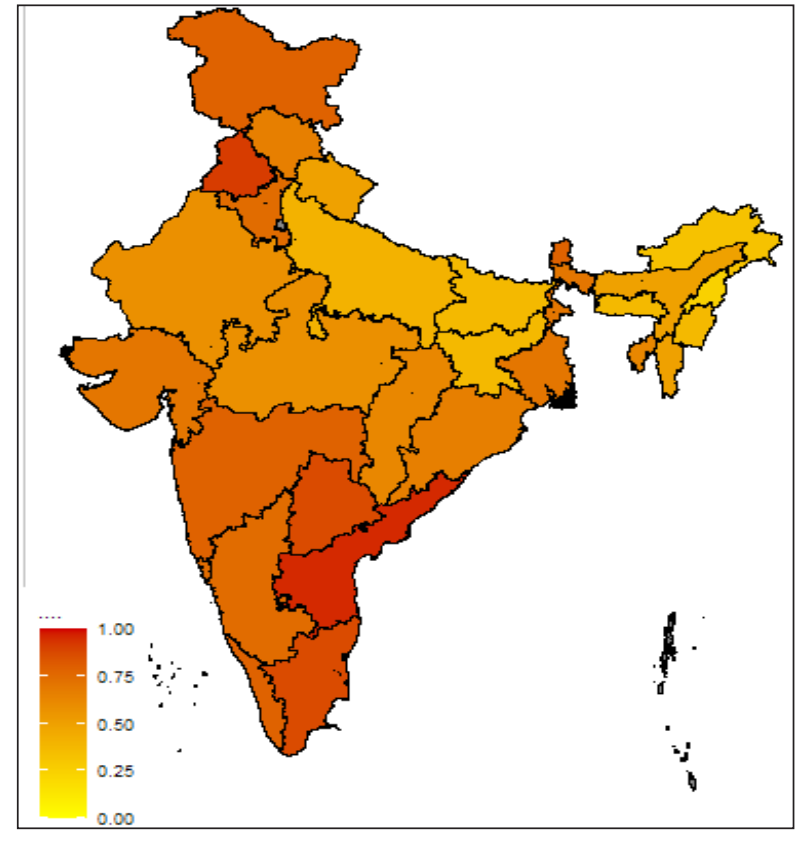

Fig. 5: Heat map of the state wise performance in reproductive and child healthcare dimension

\section{Nutrition}

This indicator is used to determine the quality of diet available to women in general as well as during pregnancy. It seeks to determine the likelihood of lifestyle disorder because of inadequate nutrition like obesity and malnutrition, anaemia and access to Iron Folic Acid.

Table 6: State wise grouping based on nutrition index performance in terms of quartile

\begin{tabular}{|l|l|l|}
\hline Quartiles & States & Description \\
\hline $\begin{array}{l}1^{\text {st }} \\
\text { Quartile }\end{array}$ & $\begin{array}{l}\text { Bihar, Goa, Gujarat, } \\
\text { Haryana, Jharkhand, } \\
\text { Madhya Pradesh, } \\
\text { Maharashtra, Rajasthan, } \\
\text { Telangana, Tripura, Uttar } \\
\text { Pradesh, West Bengal }\end{array}$ & $\begin{array}{l}\text { These states have } \\
\text { a below average in } \\
\text { majority of the 5 } \\
\text { indicators. }\end{array}$ \\
\hline $\begin{array}{l}2^{\text {nd }} \\
\text { Quartile }\end{array}$ & $\begin{array}{l}\text { Andhra Pradesh, } \\
\text { Chhattisgarh, Himachal } \\
\text { Pradesh, Jammu and } \\
\text { Kashmir, Karnataka, Tamil } \\
\text { Nadu, Uttaranchal }\end{array}$ & $\begin{array}{l}\text { These states have } \\
\text { average performance } \\
\text { in the majority of the } \\
\text { indicators with a below } \\
\text { average performance in } \\
\text { the remaining ones. }\end{array}$ \\
\hline
\end{tabular}

\begin{tabular}{|l|l|l|}
\hline $\begin{array}{l}3^{\text {rd }} \\
\text { Quartile }\end{array}$ & $\begin{array}{l}\text { Arunachal Pradesh, Assam, } \\
\text { Orissa, Punjab }\end{array}$ & $\begin{array}{l}\text { These states have } \\
\text { majority of scores } \\
\text { between 2 and 3, } \\
\text { outlier scores are } \\
\text { compensated. }\end{array}$ \\
\hline $\begin{array}{l}4^{\text {th }} \\
\text { Quartile }\end{array}$ & $\begin{array}{l}\text { Kerala, Manipur, } \\
\text { Meghalaya, Mizoram, } \\
\text { Nagaland, Sikkim }\end{array}$ & $\begin{array}{l}\text { These States have } \\
\text { a very high score, } \\
\text { between 3-4 in majority } \\
\text { of indicators. }\end{array}$ \\
\hline
\end{tabular}

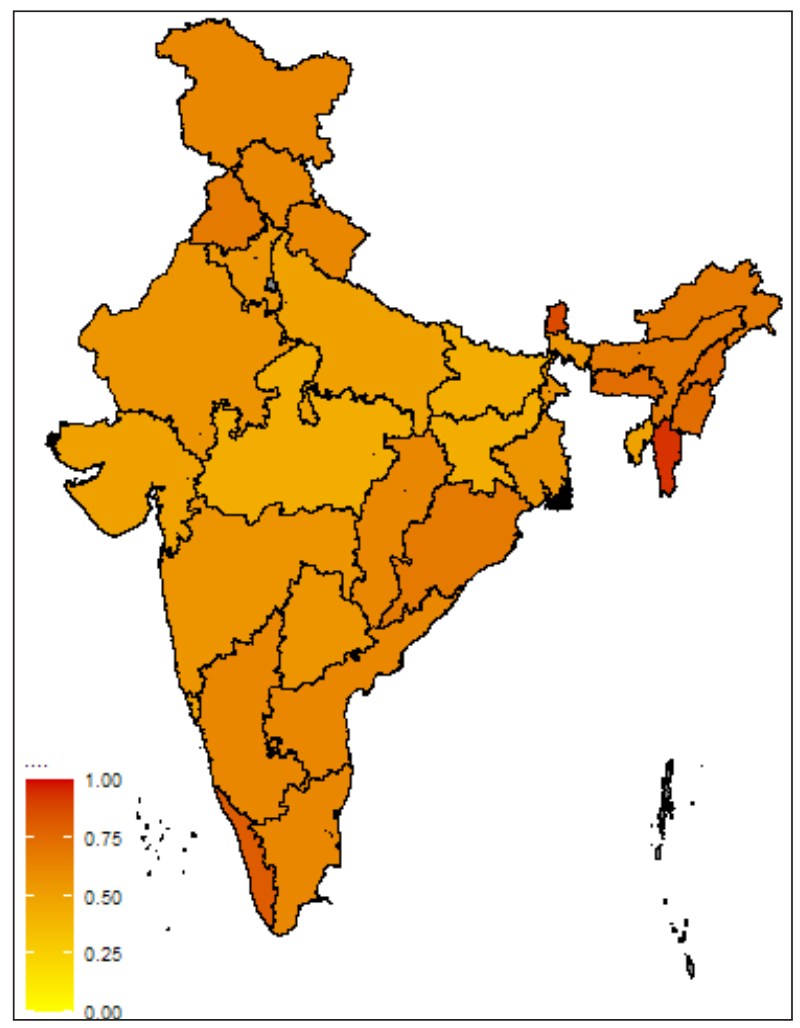

Fig. 6: Heat map of the state wise performance in nutrition dimension

\section{Geographical Indications}

* Southern states are divided with Andhra Pradesh and Telangana in first quartile, Karnataka in second, Kerala in third and Tamil Nadu in fourth quartile.

* North Eastern states like Sikkim and Mizoram are top scorers on the index, while Meghalaya, Manipur and Nagaland are in the third quartile.

* Eastern states register scores in first and second quartiles, while North Indian states of UP, MP and Bihar score the lowest in the pillar. 
$\underset{\text { AESSRA }}{J_{W}}$ Mishra et al.

\section{RESULTS}

\section{(a) PCA and Clustering}

On basis of Principal Component Analysis, we find that the index can be simplified into 6 major dimensions. Out of these, three dimensions explain significant majority of variations in original dataset. The correlation of the dimensions with the variables of the index are given below.

The three major dimensions from PCA are described below:

\section{Position of Women in Society}

The first principal component is strongly correlated with two of the original variables namely Social and capacity. The first principal component increases with increasing social and capacity scores. This indicates that these two criteria vary together. If one increases, then the remaining ones tend to increase as well. More Precisely the first principal component is a measure of capacity based on the high correlation of 0.62 .

This dimension correlates with the social barrier that women face in society: in terms of education, position in a family, early marriage, meta-preference for sons among others and also with levels of access to government welfare schemes and technology. Broadly, this indicator covers the social barriers of empowerment of women, be it those imposed by society(social) or the inherent lack of ability in current state of affairs (capacity).

\section{Access to Reproductive and Child Health Services}

The Second principal component is strongly correlated with two of the original variables namely Social and Reproductive and Child Health. The second principal

Table 7: The PCA values of the six dimension

\begin{tabular}{lllllll}
\hline & PC1 & PC2 & PC3 & PC4 & PC5 & PC6 \\
\hline Social & 0.4906421 & 0.504548 & -0.04536 & -0.11917 & -0.6933 & 0.088155 \\
RCH & 0.3227394 & -0.6937 & 0.174907 & -0.55548 & -0.16441 & 0.220091 \\
Nutrition & 0.2798105 & 0.208322 & -0.21156 & 0.011205 & 0.461681 & 0.787577 \\
Health & 0.40289 & -0.30608 & 0.350542 & 0.780209 & -0.08564 & 0.071085 \\
Economics & 0.1791839 & -0.31899 & -0.89149 & 0.186757 & -0.09982 & -0.1629 \\
Capacity & 0.6183757 & 0.159312 & 0.070368 & -0.18304 & 0.511714 & -0.5403 \\
\hline
\end{tabular}

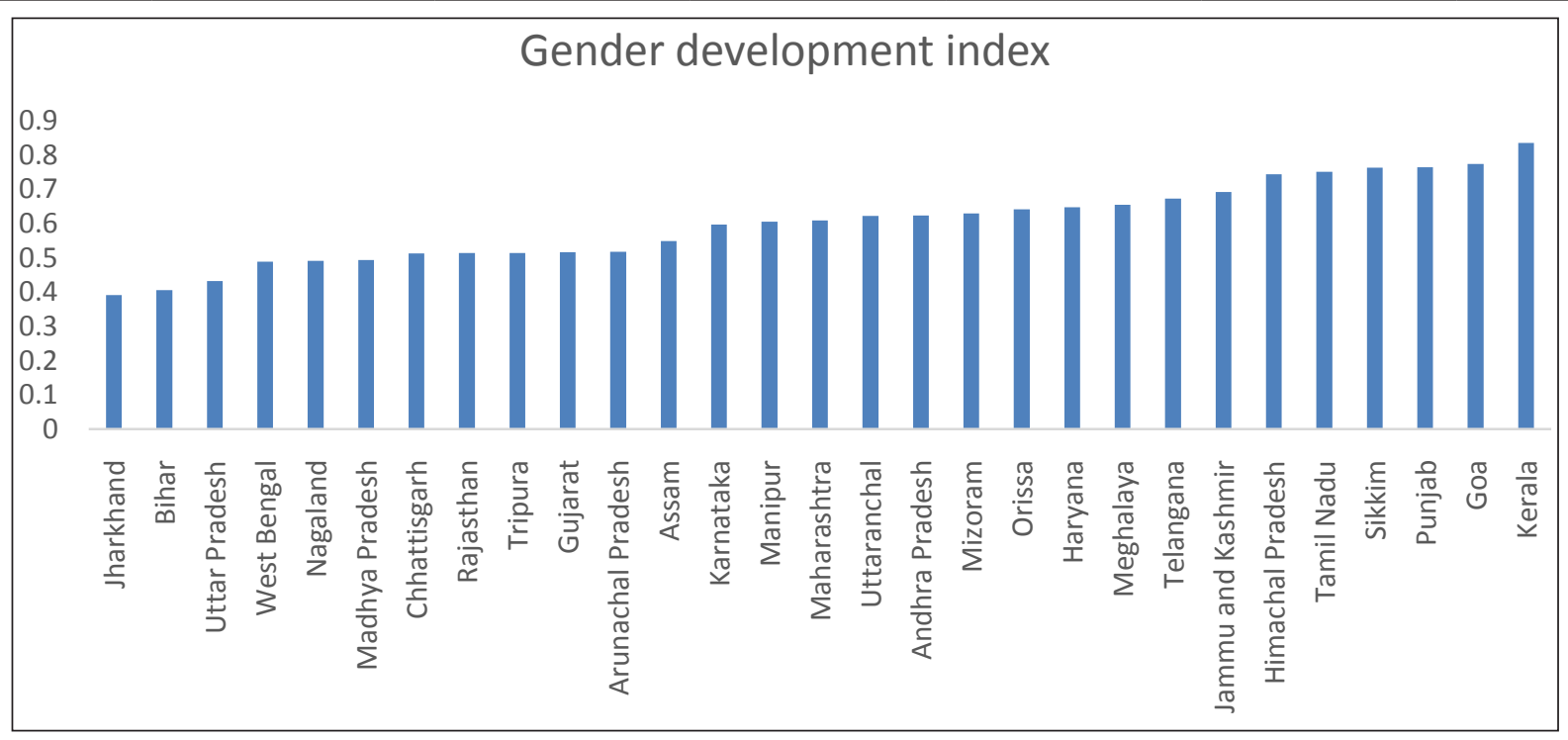

Fig. 7: State wise GDI scores 
component increases with social scores but decrease with an increase in $\mathrm{RCH}$ score. This indicates that these two criteria vary in opposite direction. However, the second PCA is more strongly correlated with $\mathrm{RCH}$ with a value of -0.69 .

This dimension correlates primarily with Reproductive and Child Health services. The dimension indicates access to $\mathrm{RCH}$ services like Institutional Delivery, Antenatal care and Postnatal care. The dimension therefore indicates barrier to $\mathrm{RCH}$ services.

\section{Economic Rights}

The third principal component is strongly correlated with one of the original variables which is economic. The third principal component decreases with economic scores with a negative correlation of -0.89 . This dimension primarily indicates the economic autonomy enjoyed by the women in a household. It is a measure of percentage of property ownership and access to financial services. Therefore, the higher the value of this principal component indicates lack of economic autonomy.

On basis of PCA we can segregate the states using K-Means clustering, into achievers(having medium to high scores in three PCs), performers (having medium scores in three PCs) and laggards (having medium to low scores in three PCs). The states can be summarized as given below.

\section{(b) Policy areas for intervention for states}

As a result of our analysis, we have highlighted the following policy areas for respective states based on their performance in the indices. These policy recommendations have been presented for the "performers" and "aspirant" states. The recommendations are based on the scores of the respective States in a given indicator with respect to its index score or a minimum score of 0.5 in individual indicator ( 0.625 for Performer). The areas highlighted are those in which the state has either underperformed with respect to its index score or with respect to fixed benchmarks like 0.5 and 0.625 . These policy areas seek to provide direction to states on improving its performance in gender development.

\section{(i) Recommendations for Aspirant States}

Table 8: Recommendation for aspirant states with respect to the corresponding PCA

\begin{tabular}{|c|c|c|c|c|}
\hline State & $\begin{array}{l}\text { Index } \\
\text { Rank }\end{array}$ & Cluster & $\begin{array}{l}\text { Policy } \\
\text { Areas for } \\
\text { Improvement }\end{array}$ & $\begin{array}{l}\text { Dimensions } \\
\text { to be } \\
\text { improved }\end{array}$ \\
\hline Jharkhand & 29 & Aspirant & $\begin{array}{l}\text { Social, } \\
\text { Capacity, RCH } \\
\text { and Nutrition }\end{array}$ & $1,2,6$ \\
\hline Bihar & 28 & Aspirant & $\begin{array}{l}\text { Social, } \\
\text { Capacity, RCH, } \\
\text { Health and } \\
\text { Nutrition }\end{array}$ & $1,2,4,6$ \\
\hline Uttar Pradesh & 27 & Aspirant & $\begin{array}{l}\text { Social, } \\
\text { Capacity and } \\
\text { RCH }\end{array}$ & 1,2 \\
\hline Nagaland & 26 & Aspirant & $\begin{array}{l}\text { Capacity, } \mathrm{RCH} \text {, } \\
\text { Nutrition and } \\
\text { Health }\end{array}$ & $1,2,4,6$ \\
\hline $\begin{array}{l}\text { Arunachal } \\
\text { Pradesh }\end{array}$ & 25 & Aspirant & $\begin{array}{l}\text { Social, } \\
\text { Capacity, RCH } \\
\text { and Nutrition }\end{array}$ & $1,2,4$ \\
\hline $\begin{array}{l}\text { Madhya } \\
\text { Pradesh }\end{array}$ & 24 & Aspirant & $\begin{array}{l}\text { Social, } \\
\text { Capacity RCH } \\
\text { and Nutrition }\end{array}$ & $1,2,4$ \\
\hline West Bengal & 23 & Aspirant & $\begin{array}{l}\text { Social, } \\
\text { Capacity, } \\
\text { Economic and } \\
\text { Health }\end{array}$ & $1,3,4$ \\
\hline Rajasthan & 22 & Aspirant & $\begin{array}{l}\text { Social, } \\
\text { Capacity, RCH } \\
\text { and Nutrition }\end{array}$ & $1,2,6$ \\
\hline Gujarat & 21 & Aspirant & $\begin{array}{l}\text { Social, } \\
\text { Capacity, } \\
\text { Economic and } \\
\text { Nutrition }\end{array}$ & $1,3,6$ \\
\hline Assam & 20 & Aspirant & $\begin{array}{l}\text { Health and } \\
\text { Nutrition }\end{array}$ & 4,6 \\
\hline Tripura & 19 & Aspirant & $\begin{array}{l}\text { Social, } \\
\text { Capacity and } \\
\text { Health }\end{array}$ & 1,4 \\
\hline Chhattisgarh & 18 & Aspirant & $\begin{array}{l}\text { Social and } \\
\text { Health }\end{array}$ & 4 \\
\hline
\end{tabular}




\section{(ii) Recommendations for Performer States}

Table 9: Recommendation for Performer states with respect to the corresponding PCA

\begin{tabular}{|c|c|c|c|c|}
\hline State & $\begin{array}{l}\text { Index } \\
\text { Rank }\end{array}$ & Cluster & $\begin{array}{l}\text { Policy } \\
\text { Areas for } \\
\text { Improvement }\end{array}$ & $\begin{array}{l}\text { Dimensions } \\
\text { to be } \\
\text { improved }\end{array}$ \\
\hline Meghalaya & 17 & Performer & $\begin{array}{l}\text { Capacity, RCH, } \\
\text { and Health }\end{array}$ & $1,2,4$ \\
\hline Manipur & 16 & Performer & $\begin{array}{l}\text { Economic, } \\
\text { RCH and } \\
\text { Health }\end{array}$ & $2,3,4$ \\
\hline Karnataka & 15 & Performer & $\begin{array}{l}\text { Social and } \\
\text { Capacity }\end{array}$ & 1 \\
\hline Odisha & 14 & Performer & $\begin{array}{l}\text { Health and } \\
\text { Nutrition }\end{array}$ & 4,6 \\
\hline Telangana & 13 & Performer & Social & 1 \\
\hline Maharashtra & 12 & Performer & $\begin{array}{l}\text { Social, } \\
\text { Economic and } \\
\text { Nutrition }\end{array}$ & $1,3,6$ \\
\hline Uttarakhand & 11 & Performer & $\begin{array}{l}\mathrm{RCH} \text { and } \\
\text { Economic }\end{array}$ & 2,3 \\
\hline $\begin{array}{l}\text { Andhra } \\
\text { Pradesh }\end{array}$ & 10 & Performer & $\begin{array}{l}\text { Social and } \\
\text { Capacity }\end{array}$ & 1 \\
\hline Haryana & 9 & Performer & $\begin{array}{l}\text { Social and } \\
\text { Nutrition }\end{array}$ & 1,6 \\
\hline
\end{tabular}

\section{CONCLUSION}

The results from the study indicate that "Gender Equality" as a policy issue when looked holistically, is far more complex. Simplification into three conventional development indicators can lose the essence of all factors that are hindering gender equality.

The study points out areas where different states of our country deviate or follow the notions held about them. For example, the quality of Reproductive and Child Health Care and health infrastructure in North Eastern states is poor, while the Social barriers to gender equality are less pronounced. Similarly, there are states like Kerala, which while excel on most of the metrics, may have some catching up to do specifically with respect to economic indicators with their regional peers. The study therefore, touches on all pillars of gender equality for all states. This analysis can be used as baseline for policy intervention in States with respect to Gender Equality.

Secondly, the dimensionality reduction conducted in the study offers a unique opportunity to determine specific areas where the intervention can be introduced, without simplifying the impact of the intervention to tradition variables like health and education. This allows states to touch broader and more abstract themes such as "Position of Women in Society" which hitherto could not be quantified in terms of actual variables. In this regard, National Family Health Survey offers an excellent opportunity to periodically track the performance of the States based on this index.

For the states which have been recommended policy action in one of the 5 main dimensions or principal components, following policy actions are recommended

\section{(a) Position of women in society}

(i) Information, Education and Communication programme on gender sensitization for boys and men in schools, colleges and workplaces to communicate the idea of gender equality and equal social position of women in society.

(ii) Regulation of patriarchal community organization ups like "Khaps" that hinder upward mobility of women in rural areas be it in social space or economic inequality.

(iii) Improving girl education metrics and learning outcomes: an area where significant work is already being done. However, access, affordability and quality of education needs to improve for empowerment of women.

(iv) Improving access to means of empowerment: Primarily means that improve independence of women in society. One example is mobility, Government of Rajasthan's "Devnarayan Chhatra Scooty Vitran Yojana" to improve access to education. Similarly, access to technology and financial instruments would be a constructive step towards making women more independent.

(b) Access to Reproductive and Child Health Services: This factor also includes policy points focusing on balanced diet and personal hygiene: 
(i) Conditional cash transfer focusing on nutrition apart from institutional birth. The regulation should make the cash transfer contingent on adoption of best practises, compliance of which could be followed through MCP cards. These best practises should not just include institutional birth but also, intake of nutrition, post-natal check-up and following best practises with respect to breast feeding.

(ii) Rationalizing the out-of-pocket expenditure on delivery in some states. Specifically, North-Eastern states to improve access and in turn maternal health.

(iii) Improving healthcare infrastructure especially in rural areas and by improving the doctor: patient ratio. Shortage of Human capital and lack of quality infrastructure touch upon 3 of the 6 pillars of Gender Development index envisaged in the study.

(iv) Promoting Male sterilization: Currently a miniscule population of men get sterilized, leading to improper family planning. A strong majority of couples undergo female sterilization, which is medically riskier. Improving on metric of male sterilization will help adapt best practises with respect to Family Planning in India.

\section{(c) Economic Empowerment}

(i) Renewed impetus to rural livelihood missions that were modelled on SHGs. Such initiatives have led to economic emancipation of women in south and their emulation elsewhere would not only boost gender equality but also propel rural economy.

(ii) Reservation in private and public sector to improve female labour force participation that has declined over the last decade. This will improve access to social security, provide social mobility and also improve social standing of women in society.

(iii) To overcome aversion of female labour due to maternal leaves, mandatory paternal leaves is recommended to overcome disincentive for employers employing women. (iv) Legal intervention in sexual harassment at work place norms to make working environment more secure and weed out grey areas in such proceedings that act as legal hindrances in prosecution. This will not only ensure quicker resolution but also keep in check frivolous complaints made under the laws already in place. Overall, this should increase employment of women and therefore lead to economic empowerment.

(v) Land ownership of women has increased, but family dynamics and position of women landowner in a family curtails their exercise of economic rights. While no state regulation can overcome such impediments in short term, social and economic empowerment of women in society is expected to improve the rights enjoyed by women in land ownership.

Source of Funding: The paper was funded by All India Women's Conference- Lucknow Branch. The paper is a part of a research report conducted for AIWC by People's Initiative. As per agreement between the organization publication in a journal is a requirement for completion of project.

\section{REFERENCES}

Bhatia, R. 2002. 'Measuring gender disparity using time use statistics', EPW., 37(33): 3464-3469.

Dholakia, K. 2005. 'Human Development Index and status of women', mimeo, The University of Texas at Dallas [http://www. utdallas.edu/, kruti/HDI_status_\%20of_women_072305.pdf] (accessed $5^{\text {th }}$ September 2020).

Economic Survey. 2018. https://www.indiabudget.gov.in/ budget2019-20/economicsurvey/index.php [accessed on $23^{\text {rd }}$ January 2021].

Mehta, A.K. 1996. 'Recasting indices for developing countries: a gender empowerment measure', EPW., 26 October.

Rai, R.K., Fawzi, W.W., Barik, A. and Chowdhury, A. 2018. The burden of iron-deficiency anaemia among women in India: how have iron and folic acid interventions fared?. WHO SouthEast Asia J. Pub. Heal., 7(1): 18-23.

Schüler, D. 2006. The uses and misuses of the Gender-Related Development Index and Gender Empowerment Measure: a review of the literature. J. Human Dev., 7(2): 161-181. 


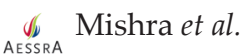

Singh, S.K., Sharma, B., Vishwakarma, D., Yadav, G., Srivastava, S. and Maharana, B. 2019. Women's empowerment and use of contraception in India: Macro and micro perspectives emerging from NFHS-4 (2015-16). Sexual \& Reproduc. Healthcare, 19: 1523.

HDR, 2020. http://hdr.undp.org/en/content/gender-inequalityindex-gii [accessed on $23^{\text {rd }}$ January 2021]. 